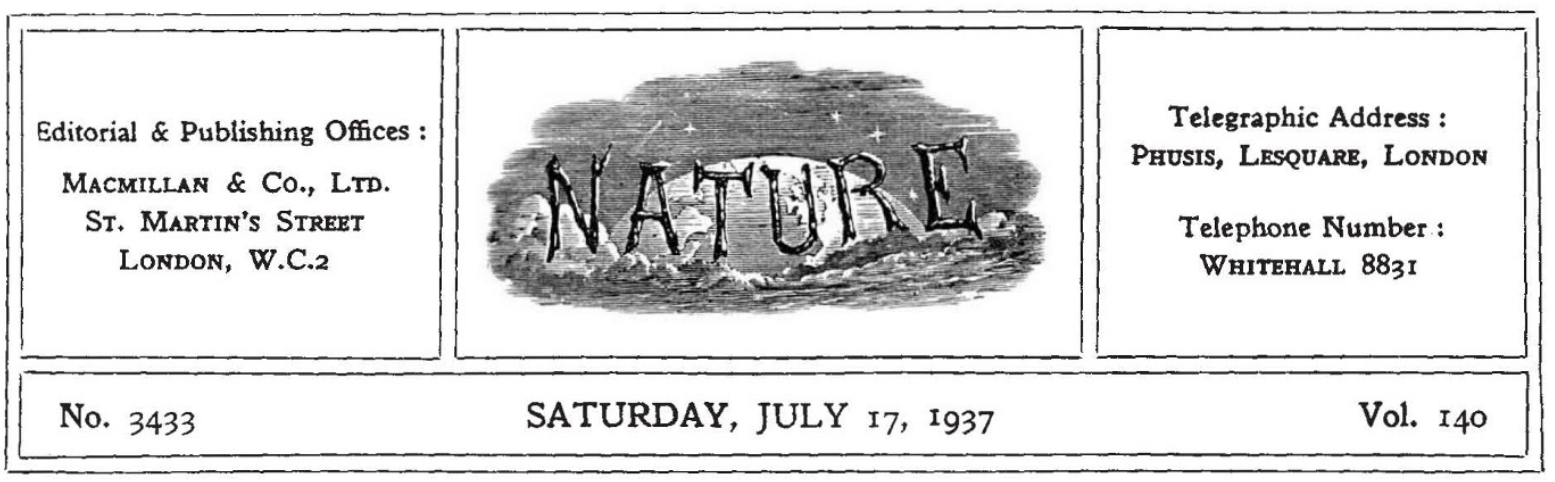

\title{
Educational Equipment for the New Age
}

$\mathrm{T}^{\mathrm{H}}$ $\mathrm{E}$ address on the university in civic training, which General Smuts delivered at his installa. tion as Chancellor of the University of Cape Town on March 2, did not receive the attention it deserved outside South Africa. It dealt with a theme which has recurred in many speeches since it was stressed by Sir James Barrett and others at the celebrations of the centenary of the University of London last year, and at the Conference on Academic Freedom at Oxford in 1935. The function of the university, General Smuts insisted, is not merely to give its students a professional qualification; it is to impart the ideals of citizenship and to fit its graduates spiritually into the world in which they had not merely to earn their living but also to play their part worthily. The university must teach the humanities-the things which furnish the student with the larger human equipment for life.

University and humanity together should form the keynote and essence of university culture, and it is in their absence that we suffer from excessive specialization and the narrow outlook responsible for so much mischief and suffering in the world to-day. Universality in its nature implies freedom from the prejudices which arise from ignorance or narrowness of outlook; it means also an impartiality, a willingness to learn and a curiosity to understand whatever life may hold for us. No less than the ordinary citizen does the university student need to avoid a single-track mentality, and his university training should give him above all a vision of harmony in the universe, of the principles of order and beauty, which should remain with him as the most satisfying and outstanding experience of his life. Science, philosophy, poetry, religion can all help to clarify and deepen that experience.
The greatest lesson that science can teach us, General Smuts urged, is respect for facts; and in the present-day tendency to follow slogans or catchwords, to worship ideologies or exalt party politics unduly, a disinterested loyalty to facts is the sovereign remedy. Equally important with this impartial spirit of science is the urbane generous spirit of humanity; and General Smuts believes that the hostility of rival fascist and communist systems to the principles of racial, religious and political toleration is a passing phase, a symptom of the confusion and unrest of the times. $\mathrm{He}$ urged that South Africa, more than any other country in the world, is a great human laboratory, where experiments in racial co-operation are essential to success.

If it is difficult for European onlookers to feel as confident as General Smuts of either fascism or communism learning the grace of toleration or respect for facts, his plea for universality and humanism undoubtedly will meet with a widespread response. Its force was undoubtedly recognized, for example, in the discussions at the symposium on the chemist in industry in Manchester last April, where the need for a wide outlook and high ideals, as well as technical or professional efficiency, was stressed by Prof. J. C. Philip. Here again the evils of over-specialization were discussed, though it was pointed out by $\mathrm{Mr}$. F. Scholefield that this danger does not lie in the kind of subject chosen for special study, and that men can be trained for a specific technical occupa. tion, without incurring this evil, if the training is given on right lines.

That these dangers should be recognized is all to the good, but the discussion referred to, at which much was said about the qualifications of the chemist for administrative posts, scarcely stressed 
sufficiently the social responsibilities of industrial management at the present time. The growing tendency for industrial efficiency to be considered not merely in terms of dividend-earning capacity or mechanical efficiency but also in relation to industrial welfare and service to the community, enhances the importance of industrial leadership having not merely high ideals and wide sympathies but also some real understanding of social problems. The industrial leader must have the wisdom of a good citizen.

The special responsibilities of the universities in this matter have been frankly recognized of late. They were stressed in the report of the University Grants Committee as well as at the Quinquennial Congress of the Universities of the Empire at Cambridge last July, and the part which the universities have played in the social surveys of the Special Areas as well as the expansion, for example, of the Economics Research Section of the University of Manchester, indicates a desire to make a practical contribution to social science and the solution of social problems on a growing scale.

Important as are these practical studies and investigations, the fundamental problem for the universities in this matter is that to which General Smuts directs attention and on which Sir Ernest Simon challenged them in an address at Cardiff last year. If the universities adequately fill their function of providing leaders and citizens who will give a wise lead to their fellows in the effort needed to eliminate weak spots in our public life and to build a better social order, the redistribution of effort in scientific research or its initiation in new . fields will follow. Moreover, effective leadership in a democracy demands a measure of co-operation and understanding from its ordinary citizens which in turn requires far higher intellectual qualities than in the authoritarian State, and here again the university has responsibilities scarcely less important than in the provision of leaders.

The two problems are in fact inextricably linked. Unless the university can provide democracy with leaders capable of taking wide and disinterested views and forming sound judgments in public affairs, and of clear and critical thinking, and able to use the appropriate scientific method of thought in the complex affairs of human society, the challenge of the authoritarian State to-day can scarcely be met. Equally the university cannot be expected to provide such leaders unless the students entering its doors have received a sufficiently wide general training in human and cultural subjects for the university to impart that stimulation and enrichment of the whole mind, independent of any specialized study the student pursues, which enable him to lead a fuller and more interesting human life and to play more adequately his part as a member of the community. Again, unless the training of the ordinary citizen in general science, in social subjects and in public affairs is wide enough to fit him to take disinterested views, to form sound judgments and to recognize and prefer wisdom and integrity in public representatives to the arts of the humbug and the demagogue, even if the supply of competent leaders is adequate, their selection by a democracy is not assured.

The heart of the problem lies accordingly in the pre-university training, especially in the postprimary or secondary school. Only as this is adequate and broad enough can the universities fulfil their own special functions of providing men and women, not merely skilled in some special subject or branch of knowledge but distinguished by a sense of values, a wide outlook, moral courage and a capacity for ereative thought which, when ripened by experience, ean be at the service of the community in any of the problems with which they may be confronted in their professional, industrial or civic life.

The question of training the university graduate for participation in public affairs cannot therefore be seriously considered apart from the question of educating the community as a whole. Sir Ernest Simon's insistence that the inefficiency of transfer of training implies that citizenship cannot be taught incidentally or indirectly, but that it can only be learnt by the direct study of the thought and life and actions of men in society, while undoubtedly right, should not lead us into any attempt to graft a special course of training in citizenship into the existing curricula of universities. The basic knowledge in these matters must be acquired at school. The university may incidentally extend that knowledge in certain subjects, but its main function here must be to supply the corrective to specialization, to quicken interest in human, social and cultural values, to inspire a vision of life as a whole, and to send out its graduates with a real interest in the affairs of the world, with a standard of values, a capacity for thinking clearly and some knowledge of the more difficult aspects of the problems of citizenship.

None the less, the university has certain special responsibilities in this field. In the first place, the need for developing some effective corrective to 
the present excessive and premature specialization is urgent and long overdue. Society cannot afford to wait until the universities are receiving students much more adequately prepared. Internal measures in the universities themselves are undoubtedly called for, even if only as temporary expedients.

In the second place, the influence which the universities exercise on secondary school teaching and curricula, if only through the scholarship system, is enormous. That influence could easily be exerted to repress the premature and disastrous specialization which often takes place in the later years at school. To require that a candidate for a university scholarship in some special subject such as history, classics or a science should attain a high standard in general subjects or even, as Sir Arthur Salter suggests, that any candidate for a degree should be required at some stage in his career to pass an examination in some aspect of the social sciences, might well be decisive. Merely to raise the age of the school-leaving examinations or matriculation so that they become, as they already are in Scotland, actual school-leaving examinations or entrance examinations to a university, might also assist to crush out the deplorable specialization of immature minds at school responsible for some of the most untoward results of the present system.

If, for these reasons, the initiative must largely lie with the universities, there are still other responsibilities in this field which they must accept. We are not concerned only with the students of the future or even with those at present in residence. It is equally important to touch those who have completed their courses and now fill all types of posts in industry or the professions, in some of which they have already assumed responsibilities of leadership. Only as they are awakened to the opportunities which confront them and come to recognize the duties and responsibilities of eitizenship can we hope to make democracy safe against its present dangers.

This, of course, is not a task for the universities alone. There is an ample field for the activities of the Association for Education in Citizenship; and the recent conference arranged by this Association at Ashridge on the "Challenge to Democracy" affords an admirable example of what is wanted. A panel of outstanding speakers was drawn from all shades of political opinion, and, excluding party politics, they discussed the clash of ideas between dictators and democrats from the point of view of believers in the ultimate value of the full and free development of each individual citizen. The first half of the programme was concerned with the essentials of democracy; the second with the formation of public opinion, including the schools; the universities, the Press and adult education. Such a conference can scarcely fail to have a powerful effect in stimulating clear thinking on everyday affairs, and the vision and moral determination essential as preludes to the action and perpetual vigilance in defence of democracy, which alone can preserve for us in these threatening days mankind's rich intellectual heritage and freedom of thought and speech.

\section{An Inquiry into "Marvels"}

\section{A Book of Marvels}

By Lieut.-Comdr. Rupert T. Gould. (The Fountain Library.) Pp. ix +180 . (London: Methuen and Co., Ltd., 1937.) 2s. 6d. net.

TH HIS book is mainly a survey of records of certain phenomena occurring between 20 B.c. and A.D. 1890 which, after sifting and weighing the available evidence, the author deems worthy of the designation "marvels". Some, however, may think the book scarcely bears out its title; indeed, the author himself, in the majority of his collected cases, carefully refrains from divulging his own views--if any were held-concerning the real significance of his "marvels". These may be summarized as follows :

(1) A line of foot-prints in the snow seen in Devon in 1855 which passed through-so it was said-locked gardens and over very high walls, haystacks, and roofs of houses, as though such things constituted no impedimenta. The impressions, which were in single file, were variously ascribed to a kangaroo, an otter, a badger, a donkey, a swan, and the Devil. Sir Richard Owen's opinion that the marks were made by a badger is discounted by Commander Gould on the score that, though Owen was an eminent palæontologist, he was given to "making dogmatic assertions, 